Boise State University

ScholarWorks

$1-1-2014$

\title{
Elizabeth Cary and Intersections of Catholicism and Gender in Early Modern England
}

Lisa McClain

Boise State University 


\title{
Elizabeth Cary and Intersections of Catholicism and Gender in Early Modern England
}

\author{
Dr. Lisa McClain \\ Boise State University
}

\begin{abstract}
Elizabeth Cary, Lady Falkland’s highly publicized conversion to Catholicism and her public abandonment by her Protestant husband, Henry Cary, have allowed historians to analyze Cary’s life primarily as one among the many lives of Catholic recusant heroines. Literary critics, in contrast, have celebrated Cary's literary corpus for its challenge to traditional ideals of early modern women as chaste, silent, and obedient, and for its re-evaluation of women's roles within marriage. ${ }^{1}$ To circumscribe our understanding of Cary in such ways obscures one of her greatest contributions. Elizabeth Cary, albeit unintentionally, provided an alternative model of Catholic womanhood that sought to negotiate a new balance between religion and gender, thus challenging assumptions about women's roles in English Catholic communities and about the rigid character of Catholicism in the Reformation era.
\end{abstract}

Her writings and life choices reveal the trajectory of Elizabeth Cary's willingness to question traditional understandings of masculinity and femininity and the centrality of her faith to her understanding of the relationship between the two. At first, as a newly married woman, she questioned male and female roles through The Tragedy of Mariam. Although one character, Salome, is willing to be the custom-breaker, the play ends with Mariam's apparent acceptance of her fate and her submission to male authority. By the 1620s, with The History of the Life, Reign and Death of Edward II, Cary again questioned gender, but with a character, Isabel, who was not only willing to be the custom breaker but who shaped her own fate in the midst of upheaval and controversy, just as Cary was doing through her conversion and struggle to live independently. By the 1630s, it was not Cary's characters who questioned but Cary herself and quite openly. Moreover, gender and religious identities were visibly interwoven in her published work and public controversies. This essay investigates how the fluctuating relationship between faith and gender, rather than one or the other, inspired many of Cary's writings and actions, opening up new sets of opportunities and challenges for Catholic women.

Throughout her life and writings, overlaps and conflicts between the demands of gender and faith are often present but unresolved. Cary often raised more issues than she settled, but this is understandable given the confusion over how gender and religion layered over the political controversies of the time. ${ }^{2}$ Religious lines between Protestants and Catholics often blurred, as Puritans proved more than willing to point out. ${ }^{3}$ But so did the lines between masculine authority and expected feminine obedience. These unstable intersections between religion and gender created opportunities for women like Elizabeth Cary to occupy unusual social spaces. Had Elizabeth Cary been a Catholic woman living in a predominantly Catholic society, her independence and boldness would hardly have been condoned. She would likely have been less willing to push the boundaries of gender as she did without the driving force of her faith. Had Henry Cary been dealing with an independent Protestant wife, he probably would not have felt compelled to cut himself off from her and thus leave her with greater freedom to act without his authority. What we see are the Carys and indeed Stuart society working through these issues, asking questions, and testing or reinforcing boundaries, effectively using intersections of gender and faith to try various options.

By examining Elizabeth Cary's written work in conjunction with her conversion to Catholicism and its aftermath, we can identify more clearly how Cary negotiated such options over time. Prior to her conversion, she was known for her closet drama, The Tragedy of Mariam, the first tragedy known to have been written by an Englishwoman. After her conversion in 1626, her literary output increased substantially. She wrote the first full-scale history penned by an Englishwoman, The History of the Life, Reign and Death of Edward II, the following year, and inserted herself into confessional controversy with her 1630 translation from French into English of a polemical treatise written by Cardinal Jacques Davy du Perron. ${ }^{4}$ Additionally, a lively correspondence ensued in which Elizabeth Cary and Henry Cary wrote letters to friends and patrons, vying for the support of king, queen, and court officials. These letters provide insight into the changes taking place among gender and religious roles during this period in English history, and according to Heather Wolfe, are the most overlooked of Cary's writings. ${ }^{5}$ 
Scholars typically interpret The Tragedy of Mariam and Edward II-both of which feature strong heroines who challenge their husbands' dominance-as reflections of Cary's challenges within her own marriage. Yet two decades and a religious conversion occurred between the writing of the two texts. Surely her Catholic beliefs and the actions she undertook to support them colored Cary's perceptions of gender roles over time, an aspect of evolution in Cary's reforming inspirations that scholars have yet to investigate.

Cary wrote Mariam between 1603 and 1604 as a young bride and as a Protestant. ${ }^{6}$ She would not convert for 23 years. Yet even then, Cary raised questions about the fluidity of gender roles and female obedience to male authority. Within the verses, Constabarus criticized his wife for taking a lover and proposing to divorce him.

“Are Hebrew women now transform'd to men?

Why do you not as well our battels fight,

And weare our armour? Suffer this, and then

Let all the world be topsie turved quite. ${ }^{7}$

Only men took lovers and could divorce, yet here a woman assumed these privileges for herself. Cary understood widespread fears about social disorder if women acted outside their traditional gender roles, but Cary allowed Salome, the wife in question, the opportunity to voice her opinion. Salome eloquently expressed a willingness to be the "custom-breaker and beginner" for all women. Of Constabarus, Salome reasoned:

"If he to me did beare as Earnest hate,

As I to him, for him there were an ease,

A separating bill might free his fate:

From such a yoke that did so much displease.

Why should such a priviledge to man be given?

Or given to them, why bard from women then?

Are men then we in greater grace with Heaven?

Or cannot women hate as well as men?

Ile be the custome-breaker: and beginner

To shew my Sexe the way to freedoms doore."

Mariam, the sympathetic protagonist, also adopted male roles and privileges, as a ruler, after she believed her husband, Herod, dead. She spoke publicly and forcefully to her subjects, yet claimed there was no unchastity in it. She even likened herself to a male ruler, Caesar, in the opening scene of the play. ${ }^{9}$ Yet in the end, Herod returned and unfairly sentenced Mariam to death. Mariam accepted her fate with heroic silence and obedience to her husband's authority.

By the time she wrote Edward II over 20 years later in 1627, Cary was an experienced wife and a convert to Catholicism. In 1622, Henry Cary, Viscount Falkland, had been appointed Lord Deputy of Ireland, and he and Elizabeth, both Protestants, resettled in Dublin. Through the exercise of his office, Henry enforced England's "harshly repressive policies toward the Catholics in Ireland."10 Elizabeth, on the other hand, met her first open Catholics. She started a workhouse for Irish Catholic children, entertained Catholic clerics, and otherwise immersed herself willingly in Irish and Catholic cultures. ${ }^{11}$ After four years, Elizabeth Cary converted to Catholicism while on a visit home to England in 1626.

Unfortunately, reports of her conversion reached her sovereign and her husband before she could break the news herself. King Charles I asked her to recant, which she refused to do based on freedom of conscience, so Charles ordered her confined to her household in London. The news reached Henry in Ireland shortly thereafter, evoking his great displeasure. Husbands of recusant women were not allowed to hold public office, thus her conversion endangered his career. ${ }^{12}$ Attempting to minimize the damage, Henry distanced himself from his wife. He immediately cut Elizabeth off financially and seized the majority of the household goods from their home in England. ${ }^{13}$

Elizabeth Cary now found herself in a situation familiar to many English Catholic women married to Protestant husbands. She had to mediate between the demands of her faith and the obedience she owed her husband, renegotiating accepted gender and religious roles. But this is a two-sided story. Protestant husbands like Henry Cary 
faced a similar challenge. Such men could not condone or support Catholicism, yet their duties as male heads of household to govern and provide for their families meant they were expected to support Catholic family members who openly and publicly defied them. No party could simply both follow the dictates of their faith and fulfill the gender role society expected of them. The nature of this tension was also such that it did not require a conscious effort on anyone's part to reshape ideas about religion and gender. The struggle to reconcile oneself to the demands of competing desires could produce such change as a byproduct.

Once Elizabeth, the repudiated wife, lived independently, she displayed a progressively greater willingness to engage in gender and religious controversy in her written and published work as well as her life choices. ${ }^{14}$ In doing so, she created a new model for Catholic women's behavior that contrasts with scholars' previous depictions of Catholic recusant women as conforming to traditional, pre-reform ideals of women's piety, wifely obedience, and motherhood. ${ }^{15}$ When the dictates of her faith conflicted with the dictates of her gender, Elizabeth Cary was inspired to work through the contradictions, at times privileging faith and at others, gender. As Gwynne Kennedy has argued, Cary, wanted "to 're-form' her situation while remaining obedient." whether doctrinal or salvific issues were involved. If they were, Elizabeth Cary openly privileged Catholicism over gender. If no such issues were at stake, she appears to place her gender role over other considerations. There were, however, several gray areas, such as her choice to write. In most situations, both religious and gender considerations are present, and we can see Cary's attempts to balance and reconcile the competing demands of each changing over time.

In the first years after her conversion, her emphasis appears to favor gendered concerns, although religious issues are always present and part of the language through which she discusses women's needs, both her characters' and her own. Her sympathetic treatment of disobedient and treasonous Queen Isabel in Edward II, for example, weaves Cary's earlier questions about feminine and masculine roles from The Tragedy of Mariam together with new concerns about the fate of the state. In prose that echoes English Catholic concerns over the future of the nowProtestant England, Isabel laments:

"My burthen is grown greater than my patience"

Yet 'tis not I alone unjustly suffer;

My tears speak those of a distressed Kingdom, Which, long time glorious, now is almost ruin'd." ${ }^{17}$

By involving herself in the literary genres of historical and political writing, Cary's aspirations have taken her from the safe, private, female-friendly closet drama into public, controversial, male-dominated literary genres, which Mihoko Suzuki maintains were the arenas generally thought to be the least welcoming to women writers in the early modern era. ${ }^{18}$

In addition to Elizabeth Cary's Edward II, she and Lord Falkland produced a substantial body of correspondence during the years between Elizabeth’s conversion in 1626 and Henry's death in 1633. Both Carys wrote numerous letters to friends and patrons, vying for support in their marital and familial conflict, which have been preserved in the public record. Additional letters written by others referring to the conflict within the family are also extant, as are examinations of Elizabeth Cary before the King's Bench and Star Chamber. The interaction between all parties involved in this epistolary exchange opens a window into the active, participatory - though often unconsciousprocess of renegotiating what it meant to be male and female as well as Catholic or Protestant in seventeenthcentury England. The struggle among the Cary family is significant not because their relationship was unique (though their circumstances were exceptional in some ways) but because the elements that drove it-the fundamentally incompatible demands of feminine and masculine social roles and competing religious faiths - were replicated in many other households throughout England. What is special is the record itself, the literary and epistolary insight into the process.

Henry Cary challenged his wife's actions in a series of scathing letters preserved in the public record. As a husband and father, Henry Cary held a well-recognized right to rule over his wife and household. A man's reputation, his sense of manhood, indeed the very order of society, all depended upon his ability to "husband," to manage and govern his "substance." Pastor Justus Menius represented this generally accepted understanding as he declared in 1528: "A husband has two functions: first, he should rule over his wife, his children, and servants and be head and master of the entire house; second, he should work and produce enough to support and feed his household."19 
Given these personal and social expectations of authority, it is understandable that in his letters Henry Cary claimed he had the natural right to mastery over his wife and that she was overstepping her capabilities and her station in ways that he eventually interpreted as embarrassing and indecent. Following Elizabeth's conversion, Lord Falkland's epistolary descriptions of his wife's character referred to her "feminine wily pretenses...assisted by feminine mediation," her "serpentyne subtlety," and her "violent contestation with him, against duty and the Lawe Matrimoniall."20

Such comments are consistent with popular views about women contained in the highly publicized debate centered on the capabilities, nature, and proper roles of women, and most previous scholars have framed the Cary debate within this context. ${ }^{21}$ Ordinary Englishfolk were exposed to the controversy through popular pamphlets that both criticized women's nature-from the low brow pamphlets of Joseph Swetnam to the high brow tracts of John Knox — and defending it—such as the treatises by Jane Anger, Rachel Speght, and Constantia Munda. ${ }^{22}$

The propagandist face of the conflict only provides one side of the story, however, and Henry's letters tell us as much about masculinity and its relationship to female behaviors as about popular views of feminine nature, and they do so within the context of Catholic-Protestant controversy. Not only could Henry Cary not control his wife but his protestations about her insubordination served to advertise this fact. His accusations of Elizabeth's incompetence rang hollow the more they were repeated, for she was clearly competent enough to sidestep the customs and laws relating to both gender and faith that stood in the way of what she wanted to accomplish as both a woman and a Catholic.

For example, following announcement of her conversion, Elizabeth refused Henry's order to go live with her mother, preferring instead to stay in London near her Catholic circle of supporters. ${ }^{23}$ Her mother, Lady Tanfield, allegedly refused to take her in. ${ }^{24}$ Henry accused Elizabeth of engineering this split with her mother in order to "remayen wheare shee is, as shee is, in despight of me, by the Power of hir popishe friends." 25 Elizabeth chose to live on Drury Lane, an area known for its high concentration of Catholics, and her friends included the French Ambassador, the Bishop of Chalcedon, Jesuits, and secular priests, as well as other London Catholics. ${ }^{26}$ Elizabeth Cary thus participated in a very different type of Catholic household and community than the women-led households typically lauded in recusant literature. Elizabeth Cary chose where she would live and with whom she would live and associate, actively resisting pressure to conform her will to her husband's.

Henry demonstrated his understanding that gender roles and religion were intimately intertwined in this controversy. Elizabeth's defiance led him to petition Charles I's officials, decrying that, "Surely her residency ought to be according to her husbands election and not her owne. Soe our religion teacheth. And if hir newe Profession teach contrary poincts of doctrine, in that as abhominable as in other things, let me first obtaine an vtter and absolute divorse." ${ }^{27}$ He asked to be separated from his wife so that "dishonour and confusion of face, with ruine of fortune may not thereby assayle me and overwhelme me; and I shalbe contented then to quitt my clayme of superioritye, and being made free, leave hir free." ${ }^{28}$ Here he declared that Elizabeth's actions shamed him, and that both masculine and Protestant authority ought to be enforced. But at the same time he acknowledged that he could not rule over his wife as a Protestant husband was expected to do. He asked for his freedom, a legal separation, a similar type of marital separation that Elizabeth Cary had noted a husband might request to free himself "from such a yoke that did so much displease" in The Tragedy of Mariam decades earlier. ${ }^{29}$ Henry recognized that he lacked the power of his gender and his faith to force Elizabeth's conformity and that he found the burden of his responsibilities to be potentially ruinous. ${ }^{30}$

As Alexandra Shepard has noted, although wives received a good deal of criticism for any disobedience to their husbands' authority, it was husbands who bore the greatest stigma by allowing it. Shepard maintains that the majority of conduct writers denigrated men who had abdicated their mastery over both themselves and their subordinates. Manhood as well as the entire social order were at stake. Patricia Crawford describes how a husband's allowance of religious disorder within his household was perhaps the worst transgression. God would lay the sins of a wife's religious disobedience upon her husband. ${ }^{31}$

But Henry went further in suggesting it was not only his honor at stake but the king's and Protestantism's as well. In a separate entreaty to Edward Conway, Secretary of State, Henry appealed to a monarch's superiority above all subjects, both Catholic and Protestant. Charles I could make Elizabeth leave her Catholic friends and return to her mother's household. He could make a mother accept her daughter. Henry declared, "The honour of our religion, and 
of his Maiesty, in the Interest of his deputy, who is become notorious ouer all the Christian world for this defection of his Wiues, and hir preualent contestation with him, ageynst duty, and the lawe Matrimoniall...doeth require that he should remoue her." ${ }^{32}$ Henry appealed directly to Charles I, saying that surely Charles's kingdom was big enough that some space away from London might be found for Elizabeth so that both he and Charles would be free of her and the "scandall and shame" she had brought upon them. ${ }^{33}$ Yet Elizabeth remained in London. Men's second responsibility as heads of household, as mentioned above, was to support their dependents. This Henry Cary also failed to do, though no doubt with justification in his eyes. Henry promptly cut off his wife financially after her conversion and continually refused to maintain her until his death in $1633 .{ }^{34}$ Elizabeth used her alleged penury as an excuse to stay in London. ${ }^{35}$ Referring to herself as a "woman distrest," she assured Lord Conway that she earnestly desired to leave London and that nothing kept her there "but sharp necessity." 36 She continued to live with her community of choice.

For her part, Elizabeth Cary's letters and published works are filled with declarations of her respect and obedience to both husband and king that are belied by her actions. ${ }^{37}$ Cary was a married woman, living independently, who defied her husband's mandates and her sovereign's will. This is not to say that Elizabeth used her religion as a convenient pretext to disobey male authority. Instead, her situation as a Catholic wife living apart from her Protestant husband created an ultimately unresolvable situation based on current religious and gendered norms. In trying to work through the contradictions, at times privileging faith and at others, gender, Elizabeth Cary unintentionally participated in constructing new norms of religious and gendered behavior for Catholic women.

Most of Elizabeth Cary's surviving letters involve requests for financial support from male authority figures, functionally asking them to assume the masculine role Henry refused to fulfill, relying, then, on traditional gender roles in her efforts to gain maintenance. This again reflects her apparent emphasis on gendered concerns in the immediate years following her conversion yet with religious concerns subtly present. Beginning in 1627, Elizabeth petitioned Charles I, Conway, and the Privy Council, presenting herself as a "distressed lady" whose husband was not fulfilling his responsibilities as he should and appealing to them as masculine men—as gentlemen, soldiers, and courtiers - to aid a lady. Charles ordered his councilors to take an interest and get the matter settled. ${ }^{38}$ The Privy Council repeatedly requested that Henry support his wife, detailing the number of servants he should provide, the level of obedience required of such servants, quality of meat and drink, healthfulness of the atmosphere, furniture, clothing, linens, horses, and a monetary allowance. In other words, this was more than a general formal request for maintenance. The Privy Council carefully prescribed the maintenance of Elizabeth's household, just as a husband was expected to provide. In informing Henry of his obligations, the Privy Council ordered him "soe to apply your selfe to the effectuall performance thereof, as that the Lady your wife may haue no further Cause to Complaine neither to his Maiestie nor this Board. ${ }^{39}$ Lord Falkland had been an ineffectual provider, and other men had needed to intervene, telling Henry to 'man up' and perform his duty. If a man's ability to support his family was in question, his worth as a man was also in doubt. ${ }^{40}$ And when Henry still refused to maintain his wife, Charles upbraided Henry for his failure and ordered the early modern equivalent of garnishing Henry's wages. ${ }^{41}$

The gendered and religious roles of the Carys were thus evolving by the very words they wrote down and the actions they took up to defend them. The debate is interesting for the ways in which the proclamations made by each party are undermined by their actions. On the surface, each writer claimed to be upholding the gender role expected of them and to be following their religious convictions. Yet none of these claims ring true, for they are all venturing into unfamiliar territory as regards intersections of the ideals of masculinity, femininity, and faith in their age. Elizabeth placed her gendered identity as a distressed lady front and center as she petitioned men to step in and relieve her want. Yet she used this poverty as an excuse to stay put, immersed in London's network of powerful Catholics that gave her access to the sacraments and support she needed. Religious considerations intersected with her declarations of herself as an obedient wife and portrayal of herself as needing the support of Protestant men.

Not only was Henry unable to exercise traditional masculine authority within the Cary family, but, as previously discussed, he could not effectively assert the authority of his religion either, and the two issues were intertwined in his mind and in those of his contemporaries. Perhaps recognizing the futility of fighting this battle and unwilling to stomach the compromises needed for a rapprochement, he sought to separate himself from Elizabeth. He tried without apparent success to carve out alternative masculine roles for himself that could withstand the challenge to his male authority as head of household that Elizabeth Cary's conversion and subsequent actions made so publicly. 
By the 1630s, after much of the marital controversy had exhausted itself, Elizabeth Cary's negotiations between gender and religion appear to be evolving in new directions, as Cary entered the polemical controversies of pre-Civil War England. In 1630, she published her translation of The Reply of the Most Illvstriovs Cardinall of Perron, to the Answeare of the Most Excellent King of Great Britaine, the First Tome, a response to the by-now-deceased Protestant King James I's claim that he belonged to the Catholic Church since he believed in the truths of the first Christians. In her dedication of the work to Henrietta Maria and epistle to her readers, she defined her identity proudly and unabashedly. "I desire to haue noe more guest at of me, but that I am a Catholique, and a Woman: the first serves for mine honour, and the second, for my excuse," although she professed she thought the translation was done well and wanting in nothing. Cary claimed she was inspired by God to undertake the work, yet she refused to ask for the traditional indulgence authors hoped readers would allow a woman writer, rejecting such demureness as "worne out forme." 42 She forthrightly categorized her translation as a "Catholicke-worke," asserting that she "could have noe other end" in producing the translation other than to inform her readers "aright." 43 Elizabeth Cary, a Catholic woman, would teach the male Protestant intellectuals at universities and at court by proclaiming both her faith and her gender as central to her identity, willingly using her religious writing in negotiating her gender identity. But, although Cary attempted to balance considerations of both Catholicism and gender, the balance appears to tilt toward faith in how and what she wrote, especially knowing she addressed a predominantly male Protestant readership.

Following Henry's death in 1633, we find Elizabeth Cary in the midst of new religious debates with men in both her written work and her life choices. As with Cary's translation of Perron in 1630, what distinguishes these later controversies from earlier ones is that Cary now appears to give more overt precedence to religious considerations over gender expectations, particularly when salvific issues were involved. For example, Lucius, as the eldest Cary son, assumed the role of head of household over his mother, brothers, and sisters after his father's death. Like his father, he was a staunch Protestant. He became best known as the leading figure of the Great Tew Circle, a group of Protestant activists and intellectuals that gathered informally at Lucius's home in Oxfordshire. In 1635, Walter Montague, a Cary family friend, publicly converted to Catholicism. He wrote a letter to his Protestant father, later published, explaining his reasons for embracing the Roman faith as the only means to salvation, against his father's and sovereign's wishes. Lucius Cary entered this public religious controversy by penning a rebuttal to Montague's explanatory letter. Elizabeth Cary decided to involve herself as well. She wrote a "letter of Controuersy" countering Lucius's arguments, which is unfortunately lost but which her daughter described "was thought the best thing shee euer writ." ${ }^{44}$ Elizabeth assumed the privilege to involve herself authoritatively in this debate, despite the public embarrassment it would cause her son. Once again, her ostensible head of household could not control her. She got away with defying male Protestant authority again.

Among the situations in which Elizabeth Cary privileged religious concerns over gender norms, perhaps her most blatant provocations came in her efforts to convert her children. For Cary, it was her children's souls that were at stake. Although men were expected to provide religious leadership within their families, Elizabeth Cary began actively converting her children to Catholicism after Henry's death, and everyone knew what she was attempting. Archbishop William Laud wrote directly to the king in July of 1634:

"The Lord Newburge hath latly acquainted me that Mrs Ann and Mrs Elizabeth Carye, two daughters of the late Lord Faulkland, are reconciled to the Church of Rome, not without the practice of the Ladye their Mother. Your Maiestye I presume remembers what sute the Lord Newburge made to you at Greenwitch; and what command you sent bye mr Secretarye Coke to that Ladye that she should forbeare working upon her daughters Consciences and suffer them to go to my Lord theire brother [Lucius Cary, a Protestant], or anye other safe place whear they might receive such instruction as was fit for them. The Lady trifled out all these Commands...I have taken hold of thiss and according to mye deutye done what I could think fittest for the present. But the greatest thing I feare is that the Mother will still be practicinge and doe all she can to hinder." 45

In spite of these protests, no one seemed able to stop her. 
Lady Falkland later subverted the intent of the law in her attempts to have her children educated abroad as Catholics. She petitioned Henrietta Maria in autumn of 1635 to send her daughter, Mary, to the Spanish court of Philip IV. The queen agreed. ${ }^{46}$ Elizabeth knew full well that Mary would live in a Catholic milieu and receive Catholic instruction at the Spanish court. Soon after Elizabeth successfully negotiated these arrangements, however, Mary declared her vocation as a nun and left England for a house of English nuns at Cambrai. ${ }^{47}$

In 1636, the government discovered her plan to spirit away two of her sons, Patrick and Henry, to receive Catholic educations in France. Even though she knew them to be still in London, Elizabeth equivocated, claiming not to know exactly where her sons were when she was brought before the King's Bench. ${ }^{48}$ The officials of Star Chamber saw through this artifice and recommended she be committed to the Tower of London but to no avail. ${ }^{49}$ When examined again, she was evasive: "beeinge againe demanded where her said sons now are, shee saith that shee thinketh they are in France, but in what parte of France she knoweth not." ${ }^{50}$ Elizabeth broke the law and obstructed the investigation into her crime with little personal consequence. ${ }^{51}$

Because a salvific issue was involved, she seems to have chosen her faith over her traditional woman's role in the family hierarchy. Yet as Mendelson and Crawford have observed, women's piety was passed particularly effectively through female networks, from parent to child, from mistress to servant. ${ }^{52}$ Although husbands possessed theoretical authority over matters of faith in the home, the day-to-day work of instructing children in the faith typically fell to mothers. As women worked and socialized together, often informally and with children present, they would discuss, challenge, reinforce, and pass on their religious beliefs to the next generations. And Elizabeth Cary was a Catholic mother who appears to have been successful at passing her faith on to her children. Although her eldest son, Lucius, was a Protestant, both younger sons - the ones sent to France-became Benedictine monks. Of her five daughters, four became Benedictine nuns at Cambrai. ${ }^{53}$ Each child experienced their mother's efforts differently and negotiated issues of spiritual choice for themselves, but the life-long importance of Cary's efforts is difficult to deny. ${ }^{54}$ She tried to balance Catholic faith with a woman's responsibilities, although her inspiration seems to tilt more toward her identity as a Catholic.

As influential as her role in her family appears to have been, however, Elizabeth Cary's impact extended well beyond this intimate circle, creating new options for Catholic women's piety, behavior, and relations within Catholic communities. Certainly in some ways, Elizabeth Cary was exceptional. As a viscountess living in London, Cary enjoyed opportunities as a Catholic and as a woman that many lesser-born or rural Catholic women may have envied. Catholic women with access to Henrietta Maria's court enjoyed a degree of royal protection and patronage as well as regular access to the Catholic sacraments. ${ }^{55}$

But in other ways, the Cary family was not unlike many English families challenged by religious non-conformity. Elizabeth and Henry Cary lived and wrote at a time in which the Stuart government hesitated to interfere in families over these issues. Although heads of household were theoretically responsible for the religious compliance of the entire household, Parliament acknowledged in 1601 that men were often powerless to change the religious views of their spouses. After 1620, the government became less involved in enforcing individual conformity within families and more interested in collecting fines and minimizing the political influence of non-conformists. ${ }^{56}$ The courts seemed little concerned with prosecuting Henry or Elizabeth, despite the bad example their situation set. Both society and government still cared deeply about the religious and gender issues involved in the Cary conflict, but once the government ceased to intervene directly to enforce conformity, individuals and families like the Carys were left to work through the contradictions and tensions between gender and religion on their own while neighbors and acquaintances watched, waited, and gossiped.

The Carys provided one very visible model that other individuals and families might emulate. The Cary conflict became public in all its aspects: the news about Elizabeth's conversion, Henry's inability to enforce his authority and refusal to support his wife, and her willingness to write publicly and boldly in defense of her faith or more modestly in request of financial support. This was a family conflict with broader implications because of this visibility. Links between family authority and political stability were common in England, particularly prior to the Civil War. Protestant cleric and popular sermonizer William Gouge suggested in 1622 that the maintenance of proper authority and order within individual households should be a priority because families preceded other types of polities and were the foundation upon which others are built. ${ }^{57}$ Henry feared for that foundation, thanks to his own family controversy. "In a short tyme," he wrote to John Coke, the new Secretary of State, "we shalle haue such vnhappy deuisions made in all the familyes of the kingdome as is now begun in myne, to the hazard of greate and 
manifest mischeefes and daungers.” Again evincing his understanding of the intersections between gender and religion, he blamed priests_- "hir seducers," "hir Popelings"—for these dangers rather than women. He believed it was through these religious men that women gained the ability to defy their husbands. Such men would be encouraged by the state's inability or unwillingness to force Elizabeth into obedience and conformity to her husband's will and begin to "prosecute theise attempts with bouldness euerywheare."58

Elizabeth saw the intersections between gender and religion differently, and as a noblewoman, Elizabeth Cary's words and actions were seen and heard more broadly than those of other Catholic women. ${ }^{59}$ They carried the authority and influence of her social rank, impacting what was thought possible for women, as individuals and as parts of families. It was not men who gave her authority to defy her husband, practice her chosen faith, live independently as part of a larger community of London Catholics, and write. It was God. She turned to God for her spiritual inspiration and to other men to meet her worldly needs. Her writings reflect how she negotiated between her religious identity and her gender identity differently when doctrinal or salvific issues were at issue, such as in her Perron translation, the Montague controversy, and her efforts to convert and educate her children. She appears to give gender issues more prominence, as in The Tragedy of Mariam and her letters requesting financial support, when these were not at issue. Both religion and gender were always present, in tension with one another. Elizabeth Cary's balancing act between them was a continual process throughout her life and writings.

Cary's efforts to reconcile the competing demands of faith and gender reflect a different type of Catholic female agency and experience emerging in Protestant England than is typically discussed. Although Catholic women are among the more well-documented women of this era, the Catholic-authored documentation typically paints idealistic portraits of such women. Catholic writers of the time certainly praised Catholic women who adhered to expectations about womanhood, wifehood, and motherhood. Such women were usually wealthy and well-connected, overseeing households far from London where Protestant authorities were less likely to bother them as they secretly welcomed and hid priests, provided a central meeting place for area Catholics to worship and receive the sacraments, and raised the next generation of Catholic children to join the mission or to marry other English Catholics. ${ }^{60}$ Scholars investigating the contributions of Catholic women to upholding underground Catholic communities emphasize these stories and characterizations of women's conformity to traditional ideals of Catholic womanhood and heroism. ${ }^{61}$ Catholic women have been described as "less conspicuous, retreating again into comparative invisibility in the records." 62

Alternatively, Protestant-authored documentation within the public record generally criticizes Catholic women, and scholarship about Protestant women rarely allows them a voice. Discussions of seventeenth-century England, for example, frequently consider the initial expansion and subsequent contraction or evolution of women's roles tied to political events from the Civil War through the Glorious Revolution. Protestant women are frequently depicted as enjoying a variety of new opportunities to participate in politics, religion, and society, and their voices as religious women figure prominently in such discussions. Catholic women's voices, however, seldom appear. When a Catholic woman's writings or activities are included, scholars may identify the woman as a Catholic but rarely analyze her legacy or contributions through the intersections of her gender with her Catholicism. ${ }^{63}$

Elizabeth Cary fits neither mold. She was anything but inconspicuous and invisible in the public record. ${ }^{64}$ And although well-connected, she was no longer wealthy. She lived in London and openly visited or hosted priests and Jesuits. She enjoyed regular access to the sacraments at Henrietta Maria's chapel. Although she ultimately persuaded most of her children to convert to Catholicism and join religious orders, they did not reside with her growing up, and she was never allowed to raise them as Catholics in a traditional Catholic household. In contrast to modern assumptions about the somewhat rigid character of early modern Catholicism, there were a diversity of Catholic women's subcultures operating within England in the seventeenth century, some traditionally based and others testing or reinforcing boundaries, effectively using intersections of gender and faith to experiment with new ways to be both a Catholic and a woman. In subsequent decades of the seventeenth century, other English Catholic women such as Mary Ward and the women of her Institute of English Ladies and the "Popish Midwife" Elizabeth Cellier would continue to broaden the boundaries of traditional gender roles, inspired by both their Catholicism and their gender. They, too, would be simultaneously lauded and criticized for their activities. Such women's living situations look different. Their activities on behalf of Catholicism look different. Their participation in Catholic communities looks different. 
Because the experiences of such women were so public, they provided, albeit unintentionally, an alternative model of Catholic womanhood that sought to negotiate new balances between religion and gender. Individuals and societies negotiate men's and women's gender roles within a web of other issues and concerns, including religion. Although sharing some similarities, Catholic women's piety is distinct from Protestant women's and Catholic men's, providing differing sets of priorities, choices, legitimations, expressions, and relationships to authority. Moreover, as a whole, English Catholic heads of households-male or female-exercised more authority over family religious life in the absence of regular priestly counsel than did heads of household in countries where Catholicism was legal..$^{65}$ Unexpected opportunities were opened to Catholic women such as Elizabeth Cary in the evolving, unstable environment in which Catholics practiced in Protestant England.

Non-traditional Catholic women such Elizabeth Cary participated actively in the confessional controversies of their time and simultaneously contributed to larger European-wide re-negotiations of the rules of masculine and feminine behavior in the seventeenth century. As Elizabeth Cary gained experience as a woman, a wife, and a Catholic, her willingness to question traditional understandings of masculinity, femininity, and religious authority evolved and matured. The trajectory of Cary's life, literary accomplishments, and preserved correspondence provides scholars with an exceptional opportunity to view the process through which such changes can occur-from the early years of her marriage with the closet drama The Tragedy of Mariam through her conversion, from her conflict with Henry Cary and willingness to appeal to accepted gender norms in the late 1620s, to the 1630s, when her gender and religious identities intersected more visibly in her later provocative religious writings and in her efforts as a Catholic mother on behalf of her children. Her involvement in the evolution of gender roles was often inadvertent and changes slow, but each time situations such as Elizabeth Cary's were made known to the public, new paradigms for Catholic women's identity and participation in the English Catholic community became possible. As she stated in her translator's epistle of Perron, Elizabeth wished no more to be known of her but that she was a Catholic and a woman. She did not have to choose one or the other but was always both, blending religion and gender in a new type of re-formation.

${ }^{1}$ Nandra Perry. "The Sound of Silence: Elizabeth Cary and the Christian Hero," English Literary Renaissance 38, no. 1 (2008): 106-141; Frances Dolan, "Reading, Work, and Catholic Women’s Biographies,” English Literary Renaissance 33, no. 3 (2003): 328-357; Stephanie Wright, “The Canonization of Elizabeth Cary,” in Voicing Women: Gender and Sexuality in Early Modern Writing, eds. Kate Chedgzoy, Melanie Hansen, and Suzanne Trill (Keele, Staffordshire: Keele University Press, 1996), 55-68; Patricia Demers, Women’s Writing in English: Early Modern England (Toronto: University of Toronto Press, 2005), 208-14; Danielle Clark, "The Tragedy of Miriam and the Politics of Marriage," in Early Modern English Drama: A Critical Companion, eds. Garrett A. Sullivan, Jr., Patrick Cheney, and Andrew Hatfield (New York: Oxford University Press, 2006), 248-59; Barbara Kiefer Lewalski, Writing Women in Jacobean England (Cambridge: Harvard University Press, 1993), 183-211.

${ }^{2}$ Gender is increasingly politicized during the English Civil War and next century. See Ann Hughes, Gender and the English Civil War (New York: Routledge, 2012); David Kuchta, The Three-Piece Suit and Modern Masculinity: England 1550-1850 (Berkeley: University of California Press, 2002).

${ }^{3}$ Henrietta Maria headed an openly Catholic community at court while Laudian churchmen, such as Dr. John Cosin, tried to keep them within an "Anglo-Catholic community." Lewalski, Writing Women, 186.

${ }^{4}$ Many other works written by Cary have been lost, such as hagiographies, letters of religious controversy, etc. See Heather Wolfe, ed., The Literary Career and Legacy of Elizabeth Cary, 1613-1680 (New York: Palgrave MacMillan, 2007), 3.

${ }^{5}$ Heather Wolfe describes Cary as a master of the literary form of letter writing. Literary Career, 10, and Elizabeth Cary, Lady Falkland: Life and Letters, ed. Heather Wolfe (Cambridge: RTM Publishing, 2001) Life and Letters, 226-7. One of Cary's daughters penned Elizabeth Cary's Life while a nun with the English Benedictine Order in Cambrai. While its hagiographic elements must be taken into consideration, it is a valuable historical source as well.

${ }^{6}$ The closet drama, based on Josephus's histories, was not published until 1613. Elizabeth Cary, The Tragedie of Mariam, The Faire Queene of Jewry (London: Thomas Creede for Richard Hawkins, 1613).

${ }^{7}$ Tragedie of Mariam, I. vi.

${ }^{8}$ Ibid., I, iv.

${ }^{9}$ Cary also portrays Mariam's execution as allegorical to Christ's crucifixion. Kim Walker. Women Writers of the English Renaissance, English Authors Series (New York: Twayne/Simon Schuster Macmillan, 1996), 134, 139.

${ }^{10}$ Lewalski, Writing Women, 184.

${ }^{11}$ Deanna Rankin, “’A More Worthy Patronesse': Elizabeth Cary and Ireland,” in Literary Career, 203-221. 
This is an author-produced, peer-reviewed version of this article. The final, definitive version of this document can be found in Women During the English Reformations: Renegotiating Gender and Religious Identity, published by Palgrave Macmillian. Copyright restrictions may apply.

${ }^{12}$ Lady Tanfield to Lady Falkland, 6 May 1627, Life and Letters, 279; Lord Falkland to Sir Edward Conway, 5 July 1627, ibid., 293-4; Walker, Women Writers, 131.

${ }^{13}$ Lord Falkland to Charles I, 8 December 1626, Life and Letters, 268.

${ }^{14}$ Catholic and Protestant women discussed conscience and its relationship to obedience and disobedience. See Katherine Gillespie. Domesticity and Dissent in the Seventeenth Century: English Women's Writing and the Public Sphere (Cambridge: Cambridge University Press, 2004); Susan Wiseman, Conspiracy and Virtue: Women, Writing and Politics in Seventeenth Century England (Oxford University Press, 2006), 108; Anthony Fletcher, Gender Sex and Subordination in England, 1500-1800 (New Haven: Yale University Press, 1999), 168; Sara Mendelson and Patricia Crawford, Women in Early Modern England (Oxford: Clarendon Press, 1998), 137-8, 253, 388.

${ }^{15}$ Robert E. Scully, SJ, Into the Lion's Den: The Jesuit Mission into Elizabethan England and Wales, 1580-1603 (St. Louis, MO: The Institute of Jesuit Sources, 2011), Scully, chapter 6; Dolan, "Reading, Work."

${ }^{16}$ Gwynne Kennedy, "Reform or Rebellion: The Limits of Female Authority in Elizabeth Cary's The History of the Life, Reign and Death of Edward II," in Political Rhetoric, Power, and Renaissance Women, eds. Carole Levin and Patricia A. Sullivan (Albany: SUNY University Press, 1995), 212. See also Patricia Crawford, Women and Religion in England, 1500-1720 (London: Routledge, 1993), 142-3.

${ }^{17}$ Elizabeth Cary, The History of the Life, Reign and Death of Edward II. King of England, and Lord of Ireland. With The Rise and Fall of his Great Favourites, Gaveston and Spenser (London: J.C. for Charles Harper, 1680) 96. Originally written in 1627 but unpublished until 1680, two forms of the text exist.

${ }^{18}$ Mihoko Suzuki, "'Fortune is a Stepmother': Gender and Political Discourse in Elizabeth Cary's History of Edward II," in Literary Career, 89. A textual genre a greater number of women embraced to express their religious and political views, and one that was more consonant with women's traditional roles, was the stitched sampler, according to Susan Frye, Pens and Needles: Women's Textualities in Early Modern England (Philadelphia: University of Pennsylvania Press, 2010), 159.

${ }^{19}$ Justus Menius, Erynnerung, Biv, in Scott H. Hendrix, "Masculinity and Patriarchy in Reformation Germany," in Masculinity in the Reformation Era, eds. Scott H. Hendrix and Susan C. Karant-Nunn, Sixteenth Century Essays \& Studies Series 83 (Kirksville, MO: Truman State University Press, 2008), 71-91.

${ }^{20}$ Lord Falkland to Conway, 5 July 1627, Life and Letters, 293.

${ }^{21}$ For examples, see Lewalski, Writing Women; Walker, Women Writers; Mary E. Burke, Jane Donawerth, Linda L. Dove, and Karen Nelson, eds., Women, Writing, and the Reproduction of Culture in Tudor-Stuart Britain (Syracuse: Syracuse University Press, 2000); Levin and Sullivan, Political Rhetoric; Demers, Women's Writing.

22 Joseph Swetnam, The Arraignment of Lewd, idle, forward, and unconstant women or the vanity of them, choose you whether, With a Commendation of wise, virtuous, and honest Women, Pleasant for married Men, profitable for young Men, and hurtful to none (1615); John Knox, The First Blast of the Trumpet Against the Monstrous Regiment of Women (1558); Jane Anger, Jane Anger her protection for women, to defend them against the scandalous reportes of a late surfeiting lover, and all other like venerians that complaine so to bee overcloyed with women's kindnesse (1589); Rachel Speght, A Mouzell for Melastomus (1617); Constantia Munda, The Worming of a Mad Dogge, or A Sop for Cerberus, the Jailer of Hell (1617).

${ }^{23}$ Lady Falkland to Conway, 24 March 1627, Life and Letters, 275; Leonard Welstead to Lord Falkland, 3 July 1628, ibid., 320. Elizabeth Cary claimed she went home to her mother, as directed, but her mother refused to take her in so she returned to London. Protestant women and women of lower social class could also refuse to live where their male heads of household dictated. See Paula McDowell, The Women of Grub Street: Press, Politics and Gender in the London Literary Marketplace 1678-1730 (Oxford: Clarendon Press, 1998), 169.

${ }^{24}$ Lady Tanfield to Lady Falkland, 6 May 1627, Life and Letters, 278.

${ }^{25}$ Lord Falkland to Conway, 5 July 1627, Life and Letters, 293-4.

${ }^{26}$ Statement of Benedicto Rollini, Master Gardener to the French Ambassador, 1630, Life and Letters, 365-6; Welstead to Lord Falkland, 20 December 1627, ibid., 307.

${ }^{27}$ Lord Falkland to Conway, 4 April 1627, Life and Letters, 277. See also Lord Falkland to Welstead, 25 June 1627, ibid., 290.

${ }^{28}$ Lord Falkland to Conway, 4 April 1627, Life and Letters, 277.

${ }^{29}$ Tragedie of Mariam, I, iv.

${ }^{30}$ If his wife could not be made to bend to his will on this matter, then Henry Cary requests a legal separation so his wife could "liue howe and wheare shee liste." Lord Falkland to Conway, 5 July 1627, Life and Letters, 293-4.

31 Alexandra Shepard, Meanings of Manhood in Early Modern England (New York: Oxford University Press, 2003), 73, 83, 86; Crawford, Women and Religion, 126-7.

${ }^{32}$ Lord Falkland to Conway, 5 July 1627, Life and Letters, 293-4.

${ }^{33}$ Lord Falkland to Charles I, 27 June 1628, Life and Letters, 318-9. 
${ }^{34}$ It appears that for a time, Henry Cary did send maintenance to Elizabeth but she refused to spend it, saying she did not wish to spend an allowance he gave against his will. Welstead to Lord Falkland, 18 April 1628, Life and Letters, 310. But on the whole, he refused to support his wife, often claiming penury himself. See Privy Council Order, 12 April 1630, ibid., 357; Charles I to Lord Coventry, ca. Jan-March 1631, ibid., 366-7.

${ }^{35}$ Lady Falkland to Conway, 24 March 1627, Life and Letters, 274.

${ }^{36}$ Ibid.

${ }^{37}$ For examples, see Lady Falkland to Conway, ca. October-December 1625, Life and Letters, 250; Lady Falkland's Petition to the Privy Council, April 1630, ibid., 357-8; Lady Falkland to Charles I, 18 May 1627, ibid., 282. See also Mendelson and Crawford, Women, 182-3; Laura Gowing, Domestic Dangers: Women, Words, and Sex in Early Modern London (Oxford: Clarendon Press, 1996), 185-6.

${ }^{38}$ Lady Falkland to Charles I, 18 May 1627, Life and Letters, 285; Conway to Sir Richard Weston, 9 June 1627, ibid., 289; Lady Falkland to Conway, ca. 26-30 June 1627, ibid., 291; Conway to Welstead, 20 July 1627, ibid., 295; Lady Falkland to Conway, 13 August 1627, ibid., 297; Lady Falkland to Conway, ca. 27-31 August 1627, ibid., 300; Conway to Weston, 8 September 1627, ibid., 301; Lady Falkland to Conway, ca. 21-30 September 1627, ibid., 301; Lady Falkland's Petition to the Privy Council, April 1630, ibid., 357-8.

${ }^{39}$ Privy Council to Lord Falkland, 31 October 1627, Life and Letters, 304-5.

${ }^{40}$ Shepard, Meanings of Manhood, 191.

${ }^{41}$ Charles I to Lord Falkland, 29 May 1628, Life and Letters, 313-4; Chancery Court Decree, 31 May 1628, ibid., 314. Henry protested vigorously. Lord Falkland to Charles I, 27 June 1628, ibid., 318. This obligation to provide for Elizabeth Cary, along with a continuation of the familial feud over authority, was passed on to the Carys' eldest son, Lucius, after Henry's death. At first, Charles I stepped in to maintain Elizabeth Cary, but eventually the Privy Council implored the new Viscount Falkland to support his mother, as he should. They were seeing, they said, no evidence that he had taken up his responsibility as the male head of household to provide for her. Privy Council Order of 16 April 1634, and Privy Council to Lucius, Lord Falkland, 9 December 1636, Life and Letters, 385, 399401.

42 Jacques du Perron, The Reply of the Most Illvstriovs Cardinall of Perron, to the Answeare of the Most Excellent King of Great Britaine, the First Tome, trans. Elizabeth Cary (Douai: Martin Bogart, 1630), epistle to the reader and dedication.

${ }^{43}$ Cary, Reply, 2r-v. Karen Nelson recognizes Cary's translation of Perron as a neglected text of Cary's. "'To Informe Thee Aright': Translating Perron for English Religious Debates,” in Literary Career, 147-163. As Susan Frye has described, Cary's works of religious controversy serve both to legitimate her writing and claim an important role for women's voices in the public sphere. Pens and Needles, 99.

${ }^{44}$ The Lady Falkland, Her Life in Life and Letters, 214. R.W. Serjeantson has attempted to deduce what Elizabeth Cary's arguments would have been in "Elizabeth Cary and the Great Tew Circle," in Literary Career, 165-182.

${ }^{45}$ William Laud to Charles I, 20 July 1634, Life and Letters, 386-7; Marie Rowlands, "Recusant Women, 15601640," in Women in English Society, 1500-1800, ed. Mary Prior (London: Methuen, 1985), 150; Crawford, Women, 60-1. Mendelson and Crawford, Women, 163.

${ }^{46}$ Henrietta Maria to Lord Aston, 17 November 1635, Life and Letters, 391-2.

${ }^{47}$ Lady Falkland to Aston, 19 December 1635, Life and Letters, 392-4.

${ }^{48}$ King’s Bench Examination of Lady Falkland, 16 May 1636, Life and Letters, 395-6.

${ }^{49}$ Star Chamber Examination of Lady Falkland, 25 May 1636, Life and Letters, 397-8.

${ }^{50}$ King’s Bench Examination of Lady Falkland [2 $\left.{ }^{\text {nd }}\right], 28$ May 1636, Life and Letters, 398-9.

${ }^{51}$ With the notable exceptions of Catholic martyrs such as Margaret Clitheroe and Ann Line, women recusants generally suffered lighter punishments than men. Their legal status under coverture meant that women were not held to be responsible for their transgressions in the same way men were. It was not unusual for courts to give Catholic women lighter sentences and fines than Catholic men, even when a group of men and women were presented for participation in the same criminal recusant activities. Scully, Into the Lion's Den, chapters 6 and 8; McClain, Lest We Be Damned, 239.

${ }^{52}$ Mendelson and Crawford, Women, 215-6, 228.

${ }^{53}$ Lewalski, Writing Women, 190. Both younger sons eventually renounced their Catholicism. Anne, Elizabeth, Lucy, and Mary Cary remained nuns until their deaths. The fifth Cary daughter, Victoria, was married in 1640 to Sir William Uvedale.

${ }^{54}$ Marion Wynne-Davies, “'To have her children with her': Elizabeth Cary and Familial Influence,” in Literary Career, 223-42.

${ }^{55}$ Lisa McClain, Lest We Be Damned: Practical Innovation and Lived Experience in Protestant England, 1559-1642 (London: Routledge, 2004), chapter 5. 
This is an author-produced, peer-reviewed version of this article. The final, definitive version of this document can be found in Women During the English Reformations: Renegotiating Gender and Religious Identity, published by Palgrave Macmillian. Copyright restrictions may apply.

${ }^{56}$ Fletcher, Gender, 220; Crawford, Women and Religion, 50, 58-9; Rowlands, “Recusant Women,” 151, 154-6, 160. Gentry and burgesses, according to Rowlands, were unwilling to allow the state such power within the family or to step on the rights of men, husbands, fathers, and masters within their own homes.

${ }^{57}$ William Gouge, Of Domesticall Duties (London, 1622) fo. 2v.

${ }^{58}$ Lord Falkland to Sir John Coke, 29 December 1626, Life and Letters, 271; Lord Falkland to Conway, 5 July 1627, ibid., 293-4.

${ }^{59}$ Mendelson and Crawford, Women, 393.

${ }^{60}$ For an in-depth discussion of this idealized image, see Rowlands, "Recusant Women," 175; Dolan, "Reading, Work.”

${ }^{61}$ Scully, Lion's Den, chapter 6; Dolan, "Reading, Work.”

${ }^{62}$ Rowlands, "Recusant Women," 149, 160-1. Catholic male heads of households often conformed outwardly to protect a family's finances and status. Catholic women were able to engage in private resistance at home. Cary challenges this generalization.

${ }^{63}$ Hughes, Gender; McDowell, Grub Street; Wiseman, Conspiracy; Gillespie, Domesticity and Dissent.

${ }^{64}$ Lewalski, Writing Women, 187.

${ }^{65}$ Mendelson and Crawford, Women, 202-3, 225-6, 388; Rowlands, “Recusant Women,” 162. 